\title{
Fish Waste Bio-Refinery Products: Its application in Organic Farming
}

\author{
B. B. Sahu, N. K. Barik, A. Paikaray, A. Agnibesh, S. Mohapatra and P. Jayasankar
}

Agri-Business Incubation Centre, ICAR-Central Institute of Freshwater Aquaculture, Bhubaneswar, Odisha, India

\begin{abstract}
Fish waste biomasses are locally available resources which contain nutrients. Fermentation of the biomass produces slurries used for plankton production and plant/agri-nutri use. Bio-refinery of fish waste material can be converted into value added biological products such as biofuels, industrial chemicals, animal and fish feed, human food, neutraceuticals and organic fertilizer, etc. Fish processing waste could be regarded as a promising renewable biomass resource for biorefineries. Hydrolysis of fish waste is aimed primarily at industrial applications of the process. Low cost and simplicity of operation by reducing the cost of material, energy consumption and labour, but maintaining high productivity are some of the important attributes at the industrial application process. Fish hydrolysate generally shows a beneficial effect on growth performances and feed utilization at low inclusion levels. The performance is postulated to be due to the balance of free amino acids, peptides and proteins in digestion, absorption and utilization.
\end{abstract}

Keywords-Bio-Refinery, Fish Processing Waste, Organic Fertiliser, Fish Hydrolysate, Organic Farming.

\section{INTRODUCTION}

Fish processing industry and fish markets produce more than $60 \%$ by-products as waste, which includes skin, heart, viscera, trimmings, liver, frames, bones and roes. These by-products contain good amount of protein rich nutrient material.

About $50 \%$ of world fish production considered as waste material, which means an expressive amount of 65.2 million metric tons of fish waste being generated globally. In addition, daily unsold fish as in markets and wastage during capture, commercialization and trash fish are regarded as low value and undesirable for human consumption, however they have potential as a feed stuff, fertilizer, animal feeds or crop fertilizers. (Kristinsson and Rasco, 2000)

Shrimp processing generates considerable quantities of solid waste in the form of head and body carapace. These body parts comprise $48-56 \%$ depending on the species (Sachindraet.al., 2005). Chitinous waste present a very important bioactive source and providing nutrients and effective microorganism to further nourish soil properties.
The important nutrient available in the organic fertilizer are nitrogen $(\mathrm{N})$, phosphorous $(\mathrm{P})$ and potassium (K),micro and macro elements which are important for plant and animal growth.

Million tons of fish processing waste are being disposed off into environment through land filling or illegal dumping activities. Dumping at organic waste material into the environment will partly contribute to the global warming phenomenon due to methane gas generation through anaerobic process occurred inside the land fill or water beds of river and streams. Methane gas has 21 times higher global warming potential (GWP) than carbon dioxide and can severely affect the environment if not properly managed.

\section{FISHERY WASTE AS A RAW MATERIAL FOR BIO-REFINERY SYSTEM}

Bio-refineries are defined as the sustainable processing of biomass into a spectrum of marketable product and energy. Bio-refinery of fish waste material can be converted into value added biological products such as biofuels, industrial chemicals, animal and fish feed, human food, neutraceuticals and organic fertilizer, etc. Fish processing waste comes under high value organic fractions. Organic fractions of the waste material can be regarded as biomass. Therefore, the term bio-refinery is derived from the words biomass and refinery.

Fish processing waste could be regarded as a promising renewable biomass resource for bio-refineries. Hydrolysis of fish waste is aimed primarily at industrial applications of the process. Low cost and simplicity of operation by reducing the cost of material, energy consumption and labour, but maintaining high productivity are some of the important attributes at the industrial application process.

\section{GREEN PROCESSING OF FISHERY WASTE}

Fishing industry creates large amount of waste every year. So there is increase demand for effective and ecological techniques to treat their waste. Biological fermentation of fish waste treat leads to organic fertilizer for potential use in animal and poultry feeds. Natural fermentation of fish waste are the process virtually independent from scale, the technology is simple, the investment is little even in 
large scale production, reduced effluents and odour problems. (Gao et al., 2006;Sahu, et al.2016 a; 2016b)

Acidic condition of fermentation can help to recover calcium to aqueous solution and increasing the nutritional value of the hydrolysate. Fermentation of fish waste is more suitable and convenient for small industries and farmers biological fermentation using lactic acid bacteria which exist naturally in the raw material or are introduced as starter culture (Vazquez, et al., 2008).

Fermentation has been studied as biological process to preserve fish waste through mixed fermentation (alcoholic/lactic) and also to remove the pungent odour. $\mathrm{pH}$ decrease in product gives evidence of a good acidification through lactic acid fermentation. The most important factor to control in the biotransformation is the $\mathrm{pH}$ decrease which must be achieved as quickly as possible in order to inhibit the growth of spoilage microorganisms in the product. Lactic acid fermentation is usually accompanied by some metabolites (bacteriocins), which may help in preservation of fermented foods.

An increase in the acid degree value (ADV) of the fat in the product is observed during the initial stage of the fermentation. The ADV increase may be due to the lipid breakdown by the lipolytic microorganisms and/or their lipases. The phenomenon is likely to occur during the $1^{\text {st }}$ stage of fermentation, while the $\mathrm{pH}$ is still about neutral so that lipolytic microorganisms can grow and consequently release their lipases. This process releases free fatty acids into the medium (Gao et al., 2006; Dao and Kim, 2011; Kim and Lee, 2009). Reduction of lipids in fish meal prepared from fish waste by yeast Yarrowialipolyticaleads to enhanced product quality during storage (Yaro et al., 2008).

Increase in non-protein nitrogen (NPN) during fermentation indicate protein breakdown leading to release of amino acids and other metabolites originating from proteins. Natural fermentation process results in continuous removal of trimethylamine produced by production of gas by yeast culture or ta a delay in formation of trimethylamine by creating conditions in the product unfavourable for the microorganisms involved in transforming the protein in such compounds (Clausen et al., 1985).

It is interesting to learn that cold fermentation has the excellent mechanism by which fish waste cannot only be preserved but also by which the fish odour is removed. The disappearance of pungent fish odour and taste could lead to ingredients responsible for being used in high proportion in animal feeds without any artefacts.

Conversion of fish waste into hydrolysate, silage and organic fertilizer using a low cost process such as cold fermentation microorganisms associated with food hygiene were monitored during cold fermentation by determination of Coliforms and Clostridium counts. The reduction in Coliform numbers ensures a goodbio preservation against undesirable and/or hazardous microorganisms. The low population observed for Clostridium indicates unfavorable conditions made by lactic acid fermentation. Indicator microorganisms like Coliforms are eliminated after three days of fermentation. This is mainly due to acidification and/or some inhibitory compounds formed by lactic acid bacteria(.LAB)

\section{FISH WASTE HYDROLYSATES}

Fish internal organs represent rich sources of enzymes and many of these exhibit high catalytic activities at relatively low concentration (Kim and Mendis, 2006). Hydrolysis processes have been developed to convert underutilized fish and fish by-products into the maketable and acceptable forms.

Fish hydrolysate generally shows a beneficial effect on growth performances and feed utilization at low inclusion levels. The performance is postulated to be due to the balance of free amino acids, peptides and proteins in digestion, absorption and utilization. Sahidi et al., 1995 confirmed that amino acid profile of protein hydrolysate is generally similar to the raw material except for sensitive amino acids such as methionine and tryptophan. Bhaskar et al., 2008, optimized the enzymatic hydrolysis of visceral waste proteins of Catla (Catlacatla) for preparing protein hydrolysate using a commercial protease.

Fish by-products contains the same valuable proteins as the fish muscle. Recovery and alteration of protein present in the fish by-product is a feasible alternative. By using fermentation and enzyme technology, it may be possible to produce a broad spectrum of food, feed and fertilizer ingredients for wide range of applications (Rustad et al., 2011).

Enzymatic hydrolysis of fish frames using papain in a pilot plant produced fish protein hydrolysate. Amino acid profile of fish protein hydrolysate was identical to that of parent substrates (fish frames) (Himonides et al., 2011).

\section{PRAWN WASTE HYDROLYSATE}

The amount of prawn processing waste can be upto $65 \%$ of initial shrimp weight and it constitutes an environmental problem. The chitin content percentage (c $\%$ ) of prawn waste (dry basis) varies from $14 \%$ to $30 \%$. The percentage of weight of protein and mineral salts can be upto $40 \%$ and $35 \%$ respectively.

Shrimp waste is an important source of bioactive molecules. Shrimp biowaste is an important natural source of carotenoids particularly that of astaxanthin and its esters. Use of strong acid and alkali in bioconversion 
of fish and prawn waste is ecologically aggressive and a source of pollution. The process also renders the protein component useless for making feed material. Traditional fermentation depends on naturally occurring microorganisms in the substrate. Spontaneous fermentation has been optimized through back slopping i.e., inoculation of the raw materials with a small quantity of previously performed successful fermentation. Spontaneous fermentation with previously performed inoculum, sugar and yeast ensures rapid acidification to conduct ensilation for converting fishery waste into industrial products. The low $\mathrm{pH}$ inhibits the growth of unwanted microorganisms. Molasses has been used as sugar source for lactic acid fermentation for preparation of silage. Molasses assisted in fermentation process is relatively inexpensive and acceptable to animals (Arbia et al., 2013).

During spontaneous fermentation protein and calcium removal is achieved by enzymatic actions and solubilization of calcium by organic acids. Spontaneous fermentation protect from microbial degradation allowing proteolytic enzymes present in muscle or viscera to liquefy and hydrolyze protein into short peptides and some of them are degraded into free amino acids (Cao, et al., 2008).

Jaggery or molasses are cheap source of sucrose and sucrose is reported to be an ideal carbohydrate source for lactic acid bacterial fermentation (Cira et al., 2002). This technique and material should be used to economically present shrimp waste and made into fertilizer and feed for aquaculture and agriculture uses.

Prawn waste hydrolysate contain large amount of pigments, mainly astaxanthin. The recovery and applications of added value products is of increasing interest. Chitin and chitosans in deacetylated form are applied in water treatment, agriculture and dietary supplement (Zhao, et al., 2010). Chitin deacetylases play very important roles in the biological attack and defense systems; they may find applications for the biological control of fungal plant pathogens or insects, pests in agriculture and for the bio control of opportunistic fungal human pathogens.

Silage preparation of prawn processing waste using molasses and yeast has been reported to be a good and economical technique to protect these biomasses from bacterial decomposition. Prawn processing by-products contain some value added nutrients for the aquaculture industry such as carotenoid pigment (mainly astaxanthin) and n-3 poly unsaturated fatty acids. Organic wastes from fish and prawn has been found to contain compounds capable of promoting plant growth.
Shrimp carotenoid increases the resistance of common carp fingerlings to ammonia induced struss. Carotenoids would find use as the pigment source in feed for ornamental fish, salmon and prawn culture. Invitro antioxidant activity of liquor from fermented shrimp biowaste reveals the antioxidants activity of the shrimp waste liquor (Babu et al., 2008). Carotenoids are prone to degradation by acids; mild treatment such as fermentation may have beneficial effect on stability of carotenoids.

Bio conversion of shrimp shell and head waste for biofungicide production (Wang et al., 2011) purified Chitinasa inhibited the hyphae extension of the phyto pathogenic fungi.

Antifungal properties of prawn waste hydrolysate

The acid/alkali liquid waste from Chitin production process could be a feed stock for antifungal material production. F.oxysporum a fungal phytopathogen equals damping off disease and the antifungal agents formed in chitin and chitosom showed suppression of swelling and lysis of hyphae. Antifungal chitinase produced by Bacillus cereus with shrimp and crab shell powder have good antifungal properties (Chang et al., 2003).

Chitin, chitosan, peptides have antioxidative and anticarcinogenic properties. Shrimp shell wastes are rich source of phenolic compounds which play an important role in antioxidant, antimicrobial, anti-inflammatory and valodilating effects.

Shrimp shell hydrolysates are rich in compounds with amino groups to enhance its antioxidant properties. It is expected that this bioactive material rich liquor have beneficial biological functions owing to inherent protein, chitin hydrolysis, astaxanthin, antifungal agent and other bioactive material produced during fermentation (Wang et al., 2005).

\section{APPLICATION OF FISH HYDROLYSATE IN AGRICULTURE}

The beneficial chemical composition of fish protein hydrolysate and fish protein concentrate has led to using their material as fertilizer, plant nutrients, fish and animal feed (Kristinsson and Rasu, 2000). Novel application taking advantage of plant growth stimulating effect of the fish hydrolysate has been studied extensively.

Fish protein hydrolysate could well become a proline and amino acid substitute in plant-tissue culture applications. The positive effect of fish hydrolysate due to proline and glutamate on plant growth was confirmed in a study (Milazzo et al., 1999). Proline and glutamate obtained from fish hydrolysate can be used for value added applications in plant propagation industry (Eguschi et al., 1997). 
Addition of fermented fish protein hydrolysate called plant catalysts at 3 lit/acre dose right from pre-plantation stage improve paddy yield between $20-30 \%$. Application of fish hydrolysate helped in eradication of stunted growth and yield improvement (Marimuthu et al., 2009).

\section{SACCHARIDES CHITOLIGO PRESENT IN THE SHRIMP SHELL HYDROLYSATE}

The mixture of chitoligo polymers have high antioxidant activity and have antitumor activity. There is a growing interest to convert chitin and chitosan into their oligomers that have better functional properties and improved absorption through human digestive tract. Enzymatic hydrolysis is more preferable for the preparation of oligomers, since this method results greater yield of oligomers with higher degree of polymerization.

Chitin and chitosan derivatives have shown good potential for removal of various aquatic pollutants. Treatment of water and waste water utilizing chitin and chitosan derivatives for removal of metal cations and metal anions, radionuclides, dyes, phenol substituted protein anions and different miscellaneous pollutants (Bhatnagar and Sillanpaa, 2009).

Chitinouswaste are very important organic fertilizer sources. In addition to their antifungal powers they also have a role in plant growth regulation and plant self defense induction. A change in microbial composition of the rhizosphere of Triticum durum wheat resulted elimination of phytopathogenic fungi, stimulation of secretion of growth hormones, secretion of antibacterial metabolites and reduced phytotoxic microbial community (Tan et al., 2010; Aizi and Cheba, 2015).

Leucine is an essential amino acid detected in shrimp head hydrolysates are good for animal feeding. Glutamic acid, aspartic acid, alanine and glycine are known to be flavor enhancers in shrimp head hydrolysates (Randriamahatody et al., 2011).

Lime treatment of shrimp head waste produced a highly digestible animal feed (Coward-kelly et al., 2006). Fish waste and shrimp head silage has been reported to be dietary sources for Nile tilapia (Srour, 2009).The development of aquaculture hampered by inadequate supply of feed stuff, particularly fish meal which is scarce and expensive.

\section{PLANT USE APPLICATIONS OF FISH HYDROLYSATE}

Wyatt and Mc Gourty (1990) received the use of fish fertilizer om agricultural crops and reported that fish fertilizer use increase the vigor and growth of plants. Liquid fish fertilizer used as spread sticker in tree fruits to maintain the health of bud wood and also the vigor of
trees.Control of codling moth and other moth pests by spraying this fertilizer.

Fish fertilizer used by table grape growers as a foliar feed to control bunch size and shape, fruit size and sugar content. Fish fertilizer provide growth hormons, trace minerals, elements and nitrogen necessary for plant tissue production

Pure inorganic nitrogen use makes explosive nitrogen response. Explosive nitrogen response is rapid and gives weeds an unwanted advantage. Nursery operator and fruit growers could benefit from increased nitrogen efficiency while using fish fertilizer.

Foliar spray and side dressing at the time of transplanting vegetables crops reduces stress and increases survivability and promotes growth potential. Studies on radish, tomatoes, corn, strawberry, lettuce, soybean, papers have demonstrated growth promoting potential.

Fish Fertilizer mixture are being used by growers of corn, soybean, horticultural crops during blooming, flowering or at other critical times in the life history of plants. Household plant growers have learnt that fish fertilizer can be used as sole source of nutrients for house plants and ornamentals.

\section{CONCLUSION}

Fishery waste occurs in all stages of fish production value chain from grower to processors, to super markets and consumers. (Gustavsson et al., 2011). One solution to secure food production, prevent depletion of fisher resources and decrease food waste may be found in the concept of the circular economy (CE). By means of closed loop fish production chains, efficiency or resource use increases and a betterbalance between economy, environment and society may be found (Ghisellini et al., 2015).

Circular economy (CE) in fishery sector comes from the involvement of all actors of the society and their capacity to link and create suitable collaboration and exchange patterns (Dittricn et al., 2015) Success stories also point out the need for an economic return on investment, involve to provide suitable motivation.

Circular business models for fishery waste aims to create solution for environmental issues by integrating novel scientific insights and technologies into new economic system.

Fish waste biomass are locally available resources which contain nutrients. Fermentation of the biomass produces slurries used for plankton production and plant/agri-nutri use. The waste biomass utilization is the objective of circular economy, to create environmental solution and offeringproducts and processes to create scientific solutions for both economic and environmental solution 
affordable to everyone in the world (Mirabells et al., 2014).

Producers, processors and retailers can individually have a great impact in reduction of fishery waste. Taking the holistic value chain in fishery to a complete business model eventually lead to a zero-fish waste production and consumption value chain in fisheries.

\section{REFERENCES}

[1] Aizi, D.E. and Cheba, B.A. (2015). Influence of chitinous waste on soil bacterial community: Biofertilizer effect and antifungal activity. Procedia Technology, 19:965-971.

[2] Aniyani, F., Buckle, K.A. (1991). Ensilaging of prawn heads. ASEAN Food J., 6:58-61.

[3] Arbia, W., Arbia, L., Adour, L., Amrane, A. (2013). Chitin extracxtion from crustacean shells using biological methods- A review. Food Technol. Biotechnol., 51(1): 12-25.

[4] Babu, C.M., Chakrabarti, R., K.R. S. Sambasirarao (2008).Enzymatic isolation of carotenoid protein camphor of shrimp head waste and the use as a source of carotenoid.LWT. - Food Science and Technology, 41:227-235.

[5] Bhaskar, N., Benila, T., Radhe, C., Lalitha, R.G. (2008).Optimization of enzymatic hydrolysis of visceral waste proteins of catla (Catlacatla) for preparing protein hydrolysate using commercial protease.Bioresource Technology, 99(2): 335-343.

[6] Bhatnagar, A and Sillanpaa, M. (2009).Application of chitin and chitose derivatives for detoxication of water and waste water- A short review. Advances in Colloid and Interface Science, 152:26-38.

[7] Cao, W., Zhang, C., Hong, P., Ji, H. (2008). Response surface methodology for autolysis parameter optimization of shrimp head and amino acids released during autolysis. Food Chem. 109: 176-183.

[8] Chalamaiah, M., Dinesh Kumar, B., Hemalatha, R., Jyothirmayi, T. (2012). Fish protein hydrolysates: Proximate composition, amino acid composition, antioxidant activities and applications: A review. Food Chem., 135:3020-3038.

[9] Chalamaiah, m., Dinesh Kumar, B., Hemlatha, C., Jyotirmayi, T. (2012). Fish protein hydrolysate proximate composition, amino acids composition, antioxidant activities and applications: A review. Food Chemistry, 135(4):3020-3038.

[10] Chang, W.T., Chin, C.S. and Wang, S.L. (2003). An antifungal chitinase produced by Bacillus cereus with shrimp and crab shell powder as a carbon source. Current microbiology, 47:102-108.
[11]Cira, L.A., Hoerta, S., Hall, G.M. and Shirai, K. (2002). Pilot scale lactic acid fermentation of shrimp waste for chitin recovery. Process.Biochem., 37:1359-1366.

[12] Clausen, E., Gildberg, A., Rao, J. (1985). Preparation and testing of autolysate of fish viscera as growth substrate for bacteria. Appl. Envir. Microbio., 50:1556-1557.

[13] Coward-kelly, G., Agobogbo, F.K., Holtzapple, M.T. (2006). Lime treatment of shrimp head waste for the generation of highly digestive animal feed. Bioresource Technology, 97:1515-1520.

[14]Dao, Y.T. and Kim, J.K.(2011). Scaled-up bioconversion of fish waste to liquid fertilizer using $5 \mathrm{~L}$ ribbon type reactor. J. Environ. Manage., 92:2441-2446.

[15] Dittrich, K., Koers, W., Berkess, F., Becke, J., Montalro, C. (2015). A value chain approaches for analyzing goal assignment in multi stake holder networks. The case of sustainable product manufacturing in the electronic industry.Paper presentation at the DRUID conference, 2015, 1517.June, Rome, Italy.

[16]Eguschi, Y., Bela, J.S. and Shetty, K. (1997).Stimulation of somatic embryogenesis in Anise (Pimpinellaanisuum) using fish protein hydrolysate and proline. J. Herbs and Spices, 5(3):61.

[17]Faid, A., Zouiten, A., Elongrakchi, A. and AchkariBagdouri, A. (1997).Bio transformation of fish waste into a stable feed ingredient. Food Chem. Col: 13-18.

[18]Gao, M., Hirata, M., Toarisaka, E and Hano, T. (2006). Acid hydrolysis of fish waste for lactic acid fermentation. Bio Resource Technology, 97:24142420.

[19] Ghisselini, P., Ciallani, C., and Ulgiati, S. (2015). A review on circular economy: the expected transition to a balanced inter interplag of environmental and economic system. J Ovrnal of cleaneProefr

[20] Gildberg, A. (1992). Recovery of proteinase and protein hydrolysates from fish viscera.Bioresource Technology, 39:271-276.

[21] Guilloca, A., Khalil, M., Adambonou, A. (1995).Effect of silage preservation on Astaxanthin form and fatty acid profiles of processed shrimp (Pandalus borealis). Waste Aquaculture, 130:351360.

[22] Gustavsson, J., Cederberg, C., Sonesson, U. (2011). Extent of food losses and waste in Global food losses and food waste, Gothernberg: Swedish Institute for food and Biotechnology (Silk). pp. 4-9.

[23] Hassan, J.E., Heath, J.L. (1986). Fermentation of fish waste for potential use in animal and poultry feeds. Agricult. Wastes, 15:1-15. 
[24]Hassan, T.E. and Heath, J.L (1986).Biological fermentation of fish waste for potential use in animal and poultry feeds. Agricultural Wastes, 15(1): 1-15.

[25] Himonides, A.T., Taylor, A.K.D., morris, A.J. (2011). Enzymatic hydrolysis of fish frames using pilot plant scale systems. Food and Nutrition Sciences, 2:586-593.

[26] Kim, J.K. (2011). Cost-effectiveness of converting fish waste into liquid fertilizer. Fisheries and aquatic sciences., 14(3):230-233.

[27] Kim, J.K. and Lee, G. (2009). Aerobically bio degraded fish meal waste as fertilizer. Environ. Res. J., 3:219-236.

[28] Kim, J.K., Dao, V.T., King, I.S. and Lee, H.H. (2010). Identification and characterization of microorganisms in earthworm viscera or the conversion of fish waste into liquid fertilizer. Bioresources Technology, 101:5131-5136.

[29] Kim, S. and Mendis, E. (2006). Bioactive compounds from marine processing by-products- A review. Food Research International, 39:383-393.

[30] Kristinson, H.G., Rasco, B.A. (2000). Fish protein hydrolysate production, biochemical and functional properties. Crit. Rev. Food Sci. Nutr., 40:43-81.

[31]Lalanides, G. and Sjorberg, 1.B. (1978).Two new methods of debittering protein hydrolysates and a fraction of hydrolysate with exceptionally high contents of essential amino acids. Journal of Agriculture and Food Chemistry, 26(3): 742-749.

[32] Marimuthu, C., Srinivasan, S., Periyasamy, K., Muthusamy, K., Ganesan, B., Thangavalu, R.D. and Veeramalai, k. (2009). Optimizing doses of organic fertilizer fermented fish liquid protein hydrolysate for eradication of stunted growth in paddy cultivation and yield improvement. International Journal of Applied Agricultural Research. 4(3):223-229.

[33] Martin, A.M. (1999). A low energy process for the conversion of fishery waste biomass. Renew. Energ., 16:1102-1105.

[34] Milazzo, M.C., Zheng, Z., Kellett, G., Haynesworth, K. and Shetty, K. (1999). Stimulation of benzyl adenine induced invitro shoot organogenesis and endogenous proline in melon (Cucumismelol) by fish protein hydrolysate in combination with protein analogues. J. Agric. Food Chem., 47(4):1771.

[35] Mirabella, N., castellari, V., and Sala, S. (2014). Current option for the valorization or toid manufacturing waste: a review. Journal of cleaner Production, 65.28-41. http://doi.org/ro.1016/J. jclepro.2016.10.051.

[36] Noguchi, M., Yamashita, M., Ara, I.S., Fujimaki, M. (1975).On bitter masking activity of a glutamic acid- rich oligopeptide fraction. Journal of Food Science, 40(2):367-370.

[37] Pedersen, B. (1994). Removing bitterness from protein hydrolysates. Food Technol., 45(10):96-98.

[38] Randriamahotody, Z., Sylla, K.S.B., Nguyen, H.T.M., Dannymoreno, C., RazanamParang, L., Bourgougnom, N. and Berge, J.P. (2011).Proteolysis of shrimp by-products Penaeusmonodomfrom Madagaskar.CyT.A- Journal of food, 9(3):220-228.

[39] Roa, J. and Gildberg, A. (1982). Fish silage: a review. CRC Crit. Rev. Food Sci. Nutri., 16:383-419.

[40] Rustad, T., Storro, I., Slizyte, R. (2011).Possibilities for the utilization of marine by-product. International Journal of Food Science and Technology, 46:20012014.

[41] Sachindra, N.M. and Bhaskar, N. (2008).Invitro antioxidant activity of liquor from fermented shrimp biowaste.Bioresource Technology, 99:9013-9016.

[42] Sachindra, N.M., Bhaskar, N., Mahendra, Kar, N.S. (2005).Carotenoids in different body components of Indian shrimps. J. Sci. Food Agric, 85:167-172.

[43] Sachindra, N.M., Bhaskar, N., Siddegouda, G.S., A.D. Satisha and P.V. Suresh (2007).Recovery of carotenoids from ensilaged shrimp waste. Bio Resource Technology, 98:1642-1646.

[44] Sahidi, F., Han, X-G., Synowjeski, J. (1995).Production and characteristics of protein hydrolysate from Capelin. Food Chem., 53:285-293.

[45] Sahu, B.B., Barik, N.K., Mohapatra, B.C., Pillai, B.R., and Jayasankar, P. (2014): Bio Fertilizer from fish waste (also in Hindi and Odia) Technical Bulletin, ICAR-CIFA, Kausalyaganga Bhubaneswar, Odisha. Pp 1-6.

[46] Sahu, B.B., Barik, N.K., Mohapatra, B.C., Pillai, B.R.,Sahu, H., Sahoo, P, Biswal N.C., Mohanty, P.K., Mohanty, U.L., Mohanta, S.K. andJayasankar, P. (2016 a):InvitroAssessment of plankton production using Fish hydrolysate in Aquatic Biology and Fisheries (IJSABF) 2(1): 14-24.

[47] Sahu, B.B., Barik, N.K., Mohapatra, B.C., Sahoo, B.N., Sahu, H., Sahoo, P, Majhi, D., Biswal N.C., Mohanty, P.K., and Jayasankar, P. (2016 b): Valorization of fish processing waste through natural fermentation with molasses for preparation of Biofertilizer and Biosupplement. Journal of Environmental Science, Computer Science and Engineering and Technology (JECET) 3(4): Sec A: pp 1849-1856.

[48] Srour, T.M. (2009). Fish waste and shrimp head silage as dietary protein source for Nile tilapia. Egyptian J. Anim. Prod. 46(1): 69-84. 
[49] Tan, T., Shang, F., Zhang, X. (2010).Current development of biorefinery in China. Biotechnology Advances, 28:543-555.

[50] Vazquez, J.A., Docasal, S.F., Prieto, M.A., Gonzalez, M.P and Murada, M.A. (2008). Growth and metabolic feature of lactic acid bacteria in media with hydrolyzed fish viscera: An approach to biosilage of fishery by-products. Bioresource Technology, 99:6246-6257.

[51] Wang, S., Liang, T., Yen, Y. (2011). Bioconversion of chitin containing waste for the production of enzymes and bioactive materials. Carbohydrate Polymers, 84(2):732-742.

[52] Westerman, P.W., Bicudo, J.R. (2005). Management considerations for organic wastes use in agriculture.Bio Resource. Technol., 96(2):215-221.

[53] Wyatt, B and Mc Gourty, G. (1990).Use of marine by products on agricultural crops.International byproducts conferences April, 1990, Anehorage, Alaska.

[54] Yaro, Y., Oikawa, H. and Satomi, M. (2008). Reduction of lipids in fish meal prepared from fish waste by yeast Yarrowialipoltica. Int. J. Food Microbiol., 121:302-307.

[55]Zhao, Y., Park, R.D., Muzzarelli, R.A.A. (2010). Chitin deacetylase properties and application. Marine Drugs, 8:24-46. 